\title{
SCREENING OF TETRACYCLINE AND FLORFENICOL ANTIBIOTIC RESIDUES IN BROILER MEAT USING ELISA AND CONFIRMATION BY LIQUID CHROMATOGRAPHY/TANDEM MASS SPECTROMETRY
}

\author{
Yeliz Tekgul $^{1 *}$, Filiz Kok ${ }^{2}$ \\ ${ }^{1}$ Department of Food Processing, Adnan Menderes University, Kosk Vocational School, Aydın, Turkey \\ ${ }^{2}$ Department of Food Hygiene and Technology, Adnan Menderes University, \\ Faculty of Veterinary Medicine, Aydın, Turkey
}

Received / Geliş: 21.08.2017; Accepted / Kabul: 11.02.2018; Published online / Online bask1: 04.04.2018

Tekgül, Y., Kok, F. (2018). Screening of tetracycline and florfenicol antibiotic residues in broiler meat using elisa and confirmation by liquid chromatography/tandem mass spectrometry. GIDA (2018) 43 (3): 403-412 doi: 10.15237/gida.GD17082

\begin{abstract}
The aim of this study was to investigate the presence of tetracycline and florfenicol residues in broiler meat that sailed in Aydin city, Turkey. For this purpose, 80 broiler meats that brands of local and national commercial were used. ELISA technique was used to investigate the presence of antibiotic residues and liquid chromatography/ tandem mass spectrometry (LC-MS/MS) technique was used to confirm the residue. As result of the ELISA, 24 samples 30\%) were positive for tetracycline. Florfenicol residues were found in any of the samples. 24 samples that is confirmed by LC-MS/MS were included an average of 30 ppb level. Residual amounts of the samples were found to be below the maximum residue limit (MRL) values.
\end{abstract}

Keywords: Florfenicol, tetracycline, ELISA, LC-MS/MS

\section{BROİLER ETLERİNDEKİ TETRASİKLİN VE FLORFENİKOL ANTİBİYOTİK KALINTILARININ ELISA İLE GÖRÜNTÜLENMESİ VE SIVI KROMATOGRAFİSİ KÜTLE/ KÜTLE SPEKTROMETRESİ İLE DOĞRULANMASI}

\section{Öz}

Bu çalısmada Aydın ilinde tüketime sunulan broiler etlerindeki tetrasiklin ve florfenikol an tibiyotik kalıntılarının araştırılması amaçlanmıştır. Bu amaçla farklı satış yerlerinden farklı zamanlarda toplanan 80 adet broiler örneği kullanılmıştır. Antibiyotik kalıntı varlığı ELISA test kitleriyle belirlenmiş ve LC MS/MS cihazı ile doğrulama yapılmıştır. ELISA test sonuçlarına göre incelenen örneklerin 24'ünün (\%30) tetrasiklin pozitif olduğu ve örneklerin hiçbirinde florfenikole rastlanılmadığ gözlenmiştir. Tetrasiklin içeren ve LC-MS/MS'de doğrulaması yapılan 24 örnekteki antibiyotik düzeyi ortalama 30 ppm olarak bulunmuştur. Bulunan değerin maksimum kalıntı düzeyinin (MRL) altıda olduğu görülmüştür.

Anahtar kelimeler: Florfenikol, tetrasiklin, ELISA, LC-MS/MS

\footnotetext{
${ }^{*}$ Corresponding author / Yazışmalardan sorumlu yazar

$\triangle$ yeliz.tekgul@adu.edu.tr $\quad$ (+90) 2562120258 / 196 


\section{INTRODUCTION}

Antibiotics have been widely used for treating infectious diseases and for promoting food producing animals growth and yields too (Aarestrup, 2012). $\beta$ - lactam, tetracyclines, chloramohenicol, sulfonamide nitrofurans, quinolones and macrocyclics groups are the most commonly used drugs for these purposes (CháferPericás et al., 2010). However, their improper and illegal use may produce residues in meat, milk, eggs, honey and the other edible tissues of animals (Passantino and Russo, 2008). The presence of antibiotic residues induces allergic reactions in humans and give rise to an increase in the antibiotic resistance of pathogenic bacteria that may result in hazardous health problems (Gomes and Demoly, 2005; Martínez, 2005; RaisonPeyron, 2001). Therefore international organizations and national regulatory agencies have installed maximum residue limits (MRLs) for veterinary drugs that are allowed to be present in foods of animal origin (Bryant Christie Inc, 2016; CODEX, 2016).

Tetracycline is an antibiotic widely used in the cultivation of poultry (Carrique-Mas et al., 2015). Florfenicol is prohibited in Turkey because of toxic property. However, in some countries the freedom of use, and the imports with countries relations to investigate the importance of the presence of residues in products offered for sale. Because of the health risks that caused by antibiotic residues (human, toxic, carcinogenic and allergenic effects and the development of resistance in microorganisms) in poultry meat and meat products should be researched to identify the residues. The monitoring of food from animal origin for the presence of antibiotic residues, broadly speaking, is usually performed by two categories of analytical methods: screening methods that include microbiological tests, and confirmatory or quantitative methods mostly based on liquid chromatography coupled to mass spectrometry (Do et al., 2016). LC-MS/MS is the most promising as a highly specific, broadly applicable detection method that provides both qualitative and quantitative data (Mavungu et al., 2009).
This study aimed to survey the occurrence and quantification on florfenicol and tetracycline residues in broiler meat samples marketed in Aydin, Turkey. To achieve this goals, we used LCMS/MS method validated to European Commission Decision 202/657/EC for confirmatory assay (European Commission, 2002).

\section{MATERIALS AND METHODS \\ Materials}

Eighty broiler samples were used which were collected from commercial products of various brands gathered from butcher's and supermarkets in and around the province of Aydin, Turkey. Samples were transported to the laboratory immediately after sampling.

\section{Methods}

\section{Preparation of Samples}

Muscular tissues which come to the laboratory for analysis, were made homogenize after excoriation of their skin and fat with the help of a blender. Acquired samples after blender process were kept and waited in nylon bags varying 50-100 $\mathrm{g}$ at -20 ${ }^{\circ} \mathrm{C}$ until the time of analysis.

\section{Sample extraction and clean-up}

$2 \pm 0.02$ grams of muscle tissue sample was weighed to put into $50 \mathrm{~mL}$-polypropylene centrifuge tube. $100 \mu \mathrm{L}$ of internal study standard solution was loaded and after a few seconds of vortex motion process $200 \mu \mathrm{L} 0.1 \mathrm{M} \mathrm{NaEDTA}$ and $10 \mathrm{~mL}$ from $70 \% \mathrm{MeOH}$ were added onto it. And, it was exposed to vortex motion again for 15 minutes and subsequently it was centrifuged at $4^{\circ} \mathrm{C}$ at $4000 \mathrm{rpm}$ for 15 minutes. $0.5 \mathrm{~mL}$ from the liquid of the top phase of each sample was transferred to clean glass tubes and upon adding $2 \mathrm{~mL}$ pure water onto tubes, then the procedure followed 2 minute-vortex-motion. Afterwards, 0.45 micron RC was filtrated so that it was replaced to $2 \mathrm{~mL}$-glass vials and injected to $20 \mu \mathrm{L}$ LC-MS/MS system (Chico et al., 2008).

\section{Immunoassay}

In order to identify the residuals of tetracycline antibiotics; Tecna SuperScreen Tetra HS ELISA test kit (code AB710/AB711) was used. And, so as to identify the residuals of florfenicol 
antibiotics; Green Spring Florfenicol ELISA test kit (LSY-10008) was used. ELISA plate washer from Nunc Maxisarp (Roskilde, Denmark), a microtiter plate reader (Wallac, model Victor 1420 multilabel counter, Turku, Finland) with photometric and time-resolved fluorometric detection was used for absorbance (490 and 650 $\mathrm{nm}$ ) and fluorescence measurements (samarium filters $340 \mathrm{~nm}, 642 \mathrm{~nm}$ ), respectively. UV-vis spectra were recorded on an Agilent 8453 diode array spectrophotometer (Palo Alto, CA).

\section{LC-MS/MS chromatographic system}

The analysis of LC-MS/MS was carried out via Agilent 6460 Triple Quadropole mass sepectrometer. Chromatographic distinction of Zorbax SB - C18, $100 \times 4.6 \mathrm{~mm}$ was performed by a column in width of $3.5 \mathrm{~mm}$. Mobile phase A, was prepared with $0.001 \% \mathrm{M}$ oxalic acid $(0.002 \%$ formic acid) in water and Mobile phase B was prepared with acetonitrile $(0.001 \%$ formic acid). Rate of flow was arranged as $0.8 \mathrm{~mL}$ per minute ( $\mathrm{mL} / \mathrm{min}$ ) and from 0 to 7.5 minute $90 \% \mathrm{~A}, 10 \%$ B; from 7.5 minute to 8 th minute $49 \%$ A, $51 \%$ B and from the 8th minute on $90 \% \mathrm{~A}$ and $10 \% \mathrm{~B}$. The injection volume was arranged as $20 \mu \mathrm{L}$ and the temperature of the column was arranged as 35 ${ }^{\circ} \mathrm{C}$.

Mass spectrometer detector was used in positive ionized mode. MS/MS conditions were given at Table 1. The heat of source block was held at 350 ${ }^{\circ} \mathrm{C}$ and electrospray capillar voltage was held at $+4000 \mathrm{~V}$. Nitrogen was used as collision gase.

Table 1. MS/MS conditions

\begin{tabular}{|ll|}
\hline Ionisation mode & ESI+ \\
\hline Collision gase & Nitrogen \\
Collision gase temprature & $350^{\circ} \mathrm{C}$ \\
Collision gase flow rate & $12 \mathrm{~L} / \mathrm{m}$ \\
API nebulising gas pressure & $45 \mathrm{psi}$ \\
Drying gas temperature & $400^{\circ} \mathrm{C}$ \\
Capillary & $4000 \mathrm{~V}$ \\
Scan time & $0.4 \mathrm{~s}$ \\
\hline
\end{tabular}

\section{Solutions}

\section{The Preparation of Mobile Phase A}

$0.126 \mathrm{~g}$ oxalic acid (Merck Millipore, Guyancourt, France) was solved in water (approximately 500 $\mathrm{mL}$ ). Then, $2 \mathrm{~mL}$ of formic acid was added into it and the volume were increased to $1 \mathrm{~L}$. It was kept in ultrasonic bath for 15 minutes.

\section{The Preparation of Mobile Phase B}

$1 \mathrm{~mL}$ of formic acid was added into the $900 \mathrm{~mL}$ Acetonitrile (Sigma-Aldrich, St. Louis, MO, USA) which is in gradient purity so as to make it $1 \mathrm{~L}$ in total amount.

\section{ELISA procedure}

\section{Tetracycline residues}

One of the test kits was made use of for the analysis of tetracycline. The kits were taken out of the refrigerator at least 30 minutes earlier than the analysis and waited at room temperature.

Previously made homogen broiler samples were taken 2 grams at a time and onto each sample was added $8 \mathrm{~mL}$ of 10 times diluted buffer. Then, each of them was homogenised with the help of vortex for 1 minute. All the instances were incubated for 15 minutes at $4{ }^{\circ} \mathrm{C}$. After incubation, instances were centrifuged at $2000 \mathrm{rpm}$ and then they all were filtered by using Whatman 1 filter paper. Each and every samples' $\mathrm{pH}$-value was arranged to 7.4 with the help of $0.5 \mathrm{~N} \mathrm{NaOH}$. Sample preparations and analysis of tetracycline were done according to the instructions of the tetracycline kit.

\section{Florfenicol residues}

Three grams were weighed from the homogenised sample for florfenicol, upon adding $6 \mathrm{~mL}$ ethyl acetate it was mixed in the shaker for 5 minutes and finally it was centrifuged at 4000 $\mathrm{rpm}$ at room temperature for 10 minutes. At the end of this process, $2 \mathrm{~mL}$ of supernatant was taken and was flown at $50-60^{\circ} \mathrm{C}$ under nitrogen. The remaining residual part was solubilized by 1 $\mathrm{mL} \mathrm{n}$-hexane. And, by adding $1 \mathrm{~mL}$ redissolving solution (which was already inside the kit and also diluted before the analysis) the remaining residual part was subjected to shaking process vigorously in the shaker for 30 seconds. Then, it was centrifuged at $4000 \mathrm{rpm}$ for 15 minutes at room temperature. Fifty microliters of centrifugalized samples were used for analysis. Sample preparations and florfenicol analysis were done according to the instructions of the florfenicol kit. All reactives and plates were ensured to be at room temperature $\left(20-25^{\circ} \mathrm{C}\right)$. 


\section{RESULTS AND DISCUSSION}

In this study, it was aimed to research residues of antibiotics in broiler meat (chicken) that is sold in the province of Aydin. In the study, 80 different broiler meat in total which were obtained from various point of sales were analyzed. The samples were analyzed with the help of ELISA test kits. Hereby, it was examined whether the residues of tetracycline and florfenicol antibiotics were present at the broiler meat or not. The obtained results were compared with the ones that were acquired by using LC-MS/MS. Parametres form $\mathrm{ms} / \mathrm{ms}$ monitoring of TCs were exposed at Table 2 .

Table 2. Parametres form MS/MS monitoring of TCs

\begin{tabular}{|lccc|}
\hline Compound & $\mathrm{MS} \mathrm{MH}^{+}(\mathrm{m} / \mathrm{z})$ & $\mathrm{MS} / \mathrm{MS}(\mathrm{m} / \mathrm{z})$ & Collision energy (Ev) \\
\hline Chlortetracycline (CTC) & 479 & 444 & 20 \\
Oxytetracycline (OTC) & 461 & 426 & 15 \\
Doxycycline (DXC) & 445 & 410 & 25 \\
Tetracycline (TC) & 445 & 410 & 15 \\
\hline
\end{tabular}

According to the results of the analysis; residues of florfenicol weren't encountered in none of the examined samples. As it was stated in the test kit which was used for tetracycline analysis; $0,0.75$, $1.5,2.5,5$ and $10 \mathrm{ng} / \mathrm{mL}$ standards were prepared. When the absorbance results obtained from standards were taken into consideration, tetracycline residues weren't determined in 56 of broiler samples. Nonetheless; the remaining 24 samples were evaluated as suspicious positive (Table 3).

Table 3. Tetracycline residues $(\mathrm{ng} / \mathrm{mL})$ in the chicken meat samples determined by ELISA

\begin{tabular}{|lcccc|}
\hline Assay & $\begin{array}{c}\text { No. of negative } \\
\text { samples, } \mathrm{n}(\%)\end{array}$ & $\begin{array}{c}\text { No. of positive } \\
\text { samples, } \mathrm{n}(\%)\end{array}$ & $\begin{array}{c}\text { Residue level } \\
(\mathrm{ng} / \mathrm{mL})(\%)\end{array}$ & $\begin{array}{c}\text { Exceed legal limit, } \\
\mathrm{n}(\%)\end{array}$ \\
\hline ELISA & $56(70)$ & & $<0.7$ & $0(0)$ \\
& $24(30)$ & $>0.7$ & $0(0)$ \\
\hline
\end{tabular}

The suspicious positive samples in terms of tetracycline according to the ELISA test results were then analyzed through LC-MS/MS device so as to determine the amount of residues. In order to measure the accuracy of used method, the antibiotics - free sample and samples which were injected $100 \mathrm{ppb}$ and $500 \mathrm{ppb}$ tetracycline were analyzed. In samples which were injected $100 \mathrm{ppb}$ antibiotics, the rate of tetracycline's revocation was determined as $96-103 \%$. On the other hand, in samples which were injected $500 \mathrm{ppb}$ antibiotics; this rate was determined as 104 $106 \%$. Chromatograms obtained as a result of the analysis were presented in figures below: Fig. 1, Fig. 2, Fig. 3 and Fig. 4.

In the present study, 80 chicken samples were subjected to LC-MS/MS for confirmatory analysis of the TC compounds. LC-MS/MS chromatograms of chicken meat samples positive for DXC $\left(31.5 \mu \mathrm{g} \mathrm{kg}^{-1}\right)$ are shown in Fig.4. The limits of detection $(\mathrm{LOD}=3.3 * \mathrm{SD} / \mathrm{m})$ and quantification $(\mathrm{LOQ}=10 * \mathrm{SD} / \mathrm{m})$ were determined by analysing the linearity assay for TC, DXC, CTC and OTC in the samples. The $\mathrm{R}^{2}$ values for the system chicken meat samples spiked with standard solutions of the TCs. Table 4 shows the results of the results were all $>0.99$ for the linear regression equations in the concentration ranges $\left(50-100 \mu \mathrm{g} \mathrm{kg}^{-1}\right)$ tested. The repeatability of the method and recovery were calculated using chicken meat samples spiked with two different concentrations of 50 and 100 $\mu \mathrm{g} \mathrm{kg}-1$ of each of the TCs. The results are presented in Table 4. 


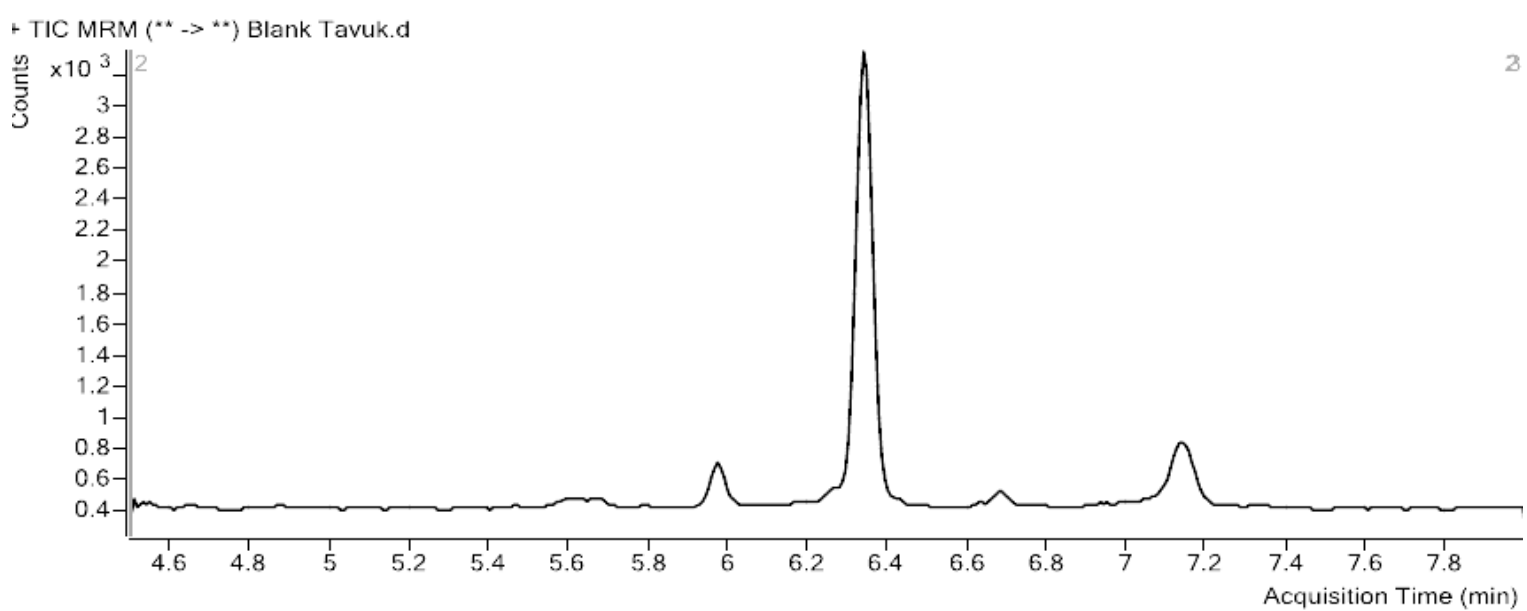

Figure 1. Typical chromatogram of a blank broiler sample

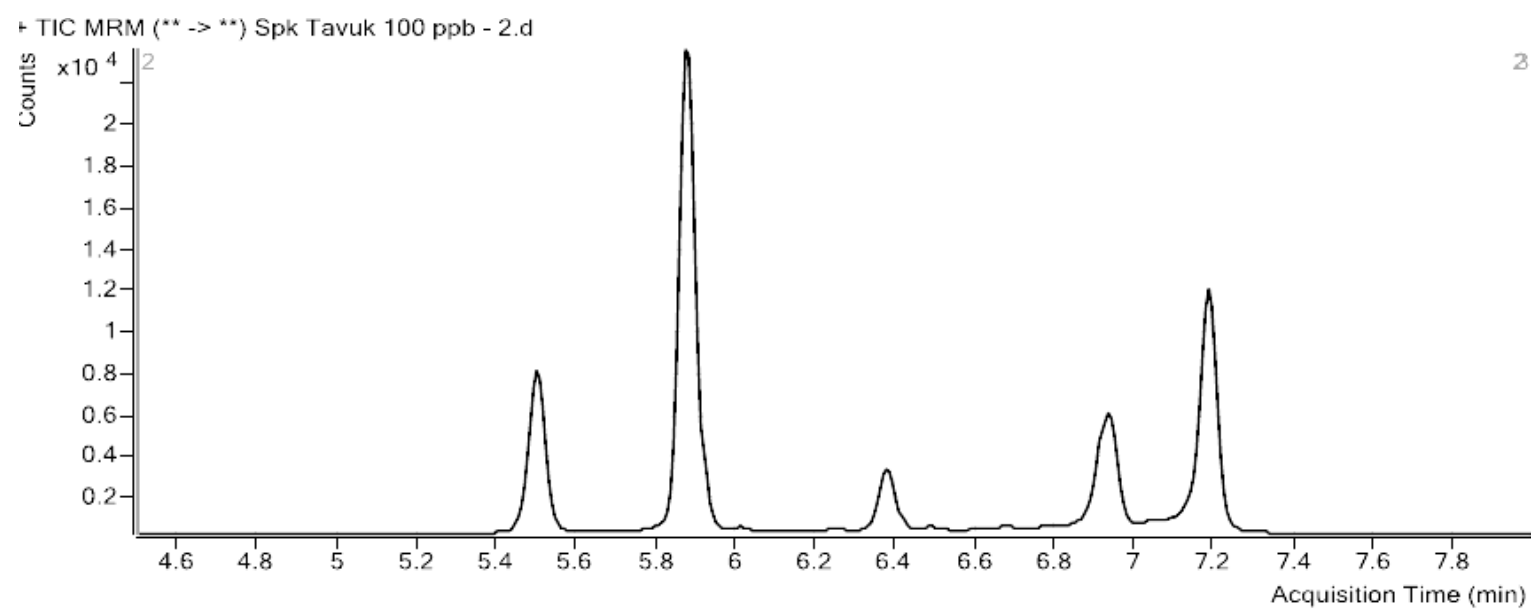

Figure. 2. Typical chromatogram of abroiler sample fortified with tetracycline (TC) at $100 \mathrm{ppb}$

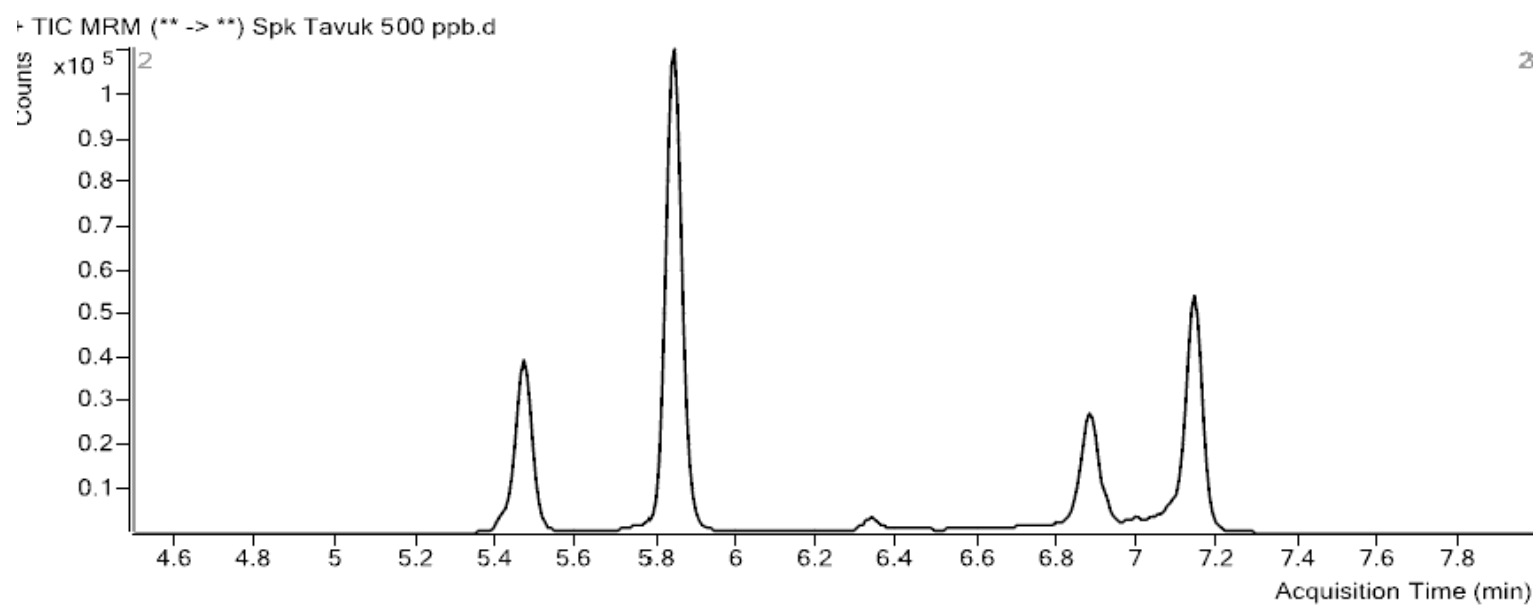

Figure 3. Typical chromatogram of abroiler sample fortified with tetracycline (TC) at $500 \mathrm{ppb}$ 


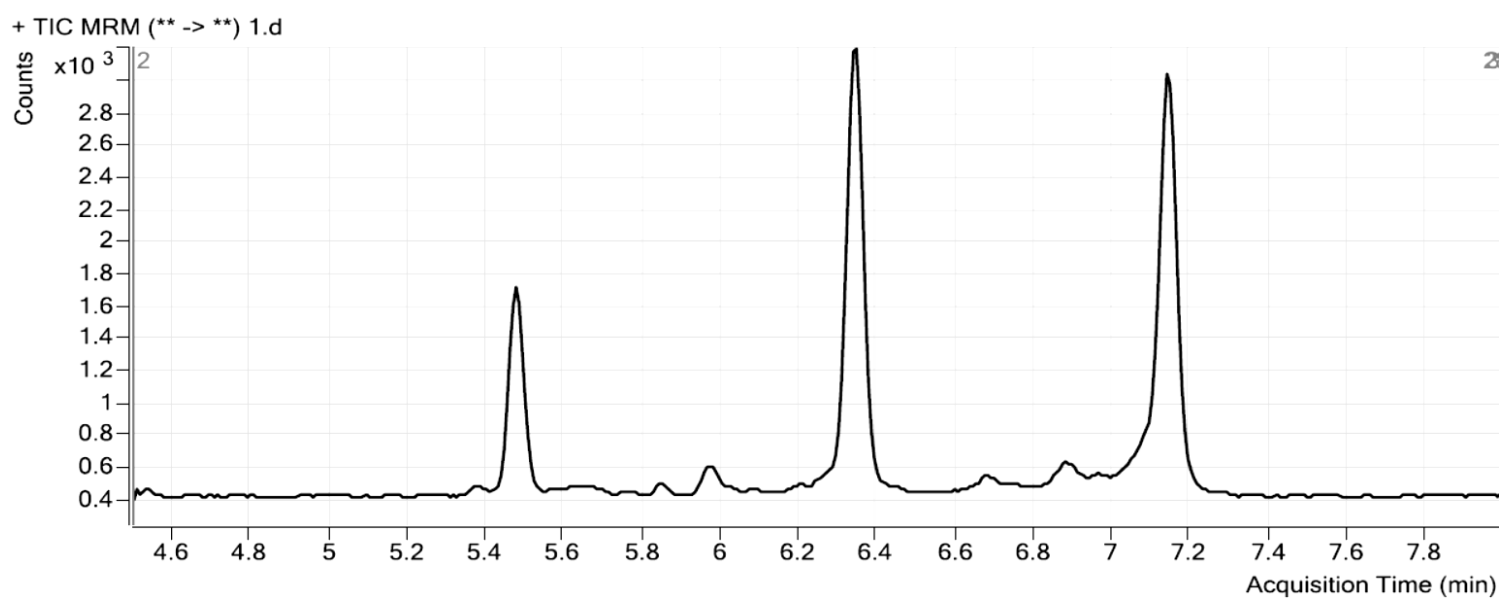

Figure 4. Typical chromatogram of broiler meat sample positive for tetracycline

Table 4. Data summary showing the LC-MS/MS results

\begin{tabular}{|lccccc|}
\hline Antibiotics & LOD $(\mu \mathrm{g} / \mathrm{kg})$ & LOQ $(\mu \mathrm{g} / \mathrm{kg})$ & Recovery $(\%)$ & RSD & $\mathrm{R}^{2}$ \\
\hline OTC & 0.8 & 2.3 & 95.1 & 8.3 & 0.9996 \\
TC & 0.3 & 0.8 & 97.8 & 9.4 & 0.9996 \\
CTC & 1.3 & 3.5 & 100.4 & 9.2 & 0.9991 \\
DXC & 8.8 & 25.9 & 105.1 & 8.7 & 0.9996 \\
\hline
\end{tabular}

The average amount of residue in suspicious positive samples on account of tetracycline residues was determined as $30.06 \mathrm{ppb}$. On the one hand, the least amount of residue in tetracycline including samples was found as $5.1 \mathrm{ppb}$. On the other hand, the highest amount of residue in tetracycline including samples was found as 76 $\mathrm{ppb}$. Among the 24 samples which were analyzed by using LC-MS/MS; it was found that in 7 samples the level of antibiotics were below the limit value.

Table 5. Obtained Residue Levels at Broiler Meat As a Result of LC-MS/MS Analysis

\begin{tabular}{|lccccc|}
\hline Sample & $\begin{array}{c}\text { Number of } \\
\text { samples }\end{array}$ & $\begin{array}{c}\text { Number of } \\
\text { positive } \\
\text { samples }\end{array}$ & $\begin{array}{c}\text { Average } \\
\text { Level } \pm(\mathrm{SD}) \\
(\mathrm{ppb})\end{array}$ & Minimum(ppb) & $\begin{array}{c}\text { Maximum } \\
(\mathrm{ppb})\end{array}$ \\
\hline $\begin{array}{l}\text { Broiler } \\
\text { meat }\end{array}$ & 80 & 24 & $30.06 \pm 0.07$ & 5.1 & 76 \\
\hline
\end{tabular}

Results obtained from LC-MS/MS (Table 5); 24 samples were evaluated in accordance with the Turkish Food Codex on Animal Origin Food Veterinary Medicine Maximum Residue Levels Edict. According to the edict mentioned above; tetracycline residue limit value for poultry is 100 $\mu \mathrm{g} / \mathrm{g}$. It is determined that the level of tetracycline in the samples anlayzed was below than allowed limits.

ELISA test was applied for the purpose of determining and investigating antibiotics residues in broiler meat sold in the province of with Aydin. At the end of this investigation process via ELISA test, it was concluded that 24 of the samples were 
evaluated as suspicious positive in terms of tetracycline group antibiotics residue; whereas the presence of florfenicol residue wasn't detected in the whole 80 samples. In order to confirm the exact amount of residue in 24 suspicious positive sample, LC-MS/MS device was used. According to the analysis results; it was observed that the amount of tetracycline in the whole 24 samples was below the MRL values.

In studies conducted in our country in this context; Acet et.al. (1998) stated that upon giving oxytetracycline $(20 \mathrm{mg} / \mathrm{kg})$ and tetracycline $(50$ $\mathrm{mg} / \mathrm{kg}$ ) orally to the broiler chicken, residues of oxytetracycline were encountered only in kidneys at the level of $0.32-0.56 \mu \mathrm{g} / \mathrm{g}$, residues of tetracycline were detected in all the tissues except from plasma at the level of $0.080-0.240 \mu \mathrm{g} / \mathrm{g}$.

Akar (1991) investigated residues of chloramphenicol, erythromycin, monensin, and tylosin with the method of lamellae chromatography / bioautography in total 350 samples of which 175 chicken meat and 175 chicken liver. The amounts of residues found in chicken meat and chicken liver could be seen below:

$2.3 \%$ chloramphenicol, $2.3 \%$ erytromycin and $1.1 \%$ tylosin residues were present in chicken meat. Also; $0.57 \%$ chloramphenicol, $1.4 \%$ erytromycin, $1.7 \%$ tylosin residues were present in chicken liver.

Obekci (2002) investigated 200 chicken meat and 200 chicken liver samples that he obtained from various cities of Turkey with HPLC method. He reported that residues at the rate of $8.1 \%$ oxytetracycline, $7 \%$ tetracycline and $5.5 \%$ chlortetracycline were found in chicken meat and residues at the rate of $74 \%$ oxytetracycline, $47 \%$ tetracycline and 5.5\% chlortetracycline were found in chicken liver.

Bergner-Lang et.al. (1993) reported that from the samples of 517 kidneys, 312 chichken meat and liver; they respectively detected antibiotics residues in $223(43 \%)$, in $135(43 \%)$ and in 18 (45.59). Moreover, they reported that 151 of samples $(10-13.5 \mu \mathrm{g} / \mathrm{kg})$ had tetracycline residues;
60 of samples $(0.5-100 \mu \mathrm{g} / \mathrm{kg})$ had chloramphenicol residues and 2 of them (12-250 $\mu \mathrm{g} / \mathrm{kg}$ ) had quinolone residues.

It was searched for chloramphenicol residues with intertest and three plate test methods in 444 raw and pasteurized milk samples provided by public and private sector enterprises in around Ankara. 78 positive (17.56\%), 65 suspicious $(14.63 \%)$ and 301 negative $(67.79 \%)$ results were obtained with intertest method. 24 positive $(5.40 \%), 1$ suspicious $(0.22 \%)$ and 419 negative $(94.36 \%)$ results were obtained by three plate method with B. Subtilis (Onal et al., 1993).

Lee et. al. (2005), analyzed 13 antibiotics contained tetracycline, macrolide, penicilin, aminoglycoside and chloramphenicol varieties with microbiological tests in various animal products. They reported that from the 459 samples of 34 were suspicious positive.

Sajid et al. (2016) detected that out of 80 poultry meat samples only 4 samples were positive for antibiotic residues. The highest concentrations of antibiotic residue found in these tissues were tetracycline (8\%) followed by ampicilin (4\%), streptomycine $(2 \%)$ and aminoglycosides $(1 \%)$ as compared to other antibiotics like sulfonamides, neomycine and gentamycine.

Wang et al. (2017) screened 20 common antibiotic (three tetracyclines, four fluoroquinolones, three macrolides, three b-lactams, four sulfonamides, and three phenicols) residues in 125 samples from common type of livestock and poultry meat, milk and aquatic products in Shanghai by ultraperformance liquid chromatography coupled to high-resolution quadrupole time-of-flight mass spectrometry. Antibiotics were found in $28.6 \%$ of livestock and poultry meat $35.3 \%$ for pork and $22.2 \%$ for chicken), $10.6 \%$ of milk, and $52.1 \%$ of aquatic products.

Salehzadeh et al. (2006) reported that tetracycline residue above maximum residual limits (MRLs), which were $27.77 \%, 95.55 \%$ and $18.88 \%$ in muscles, liver and kidney samples respectively. Hussein and Khalil (2013) exposed the residual of tetracycline in poultry meat ranged from 0.156 
$\mu \mathrm{g} / \mathrm{g}$ to $0.900 \mu \mathrm{g} / \mathrm{g}$ with a mean value of $0.394 \pm 0.111 \mu \mathrm{g} / \mathrm{g}$. Tajik et al. (2010) reported chloramphenicol level as minimum and maximum levels of 0.54 and $155.2 \mathrm{ng} / \mathrm{g}$ in the kidney and liver, respectively.

In Iran, $22 \%$ of samples were reported positive and containing sulfonamides of that $1 \%$ contained aminoglycosides and none of sample contained [beta]-lactams, tetracyclines (Farideh et al., 2014). In Algeria, similar work has recorded $86.20 \%$ positive samples including $64.83 \%$ containing [beta]-lactam or tetracyclines (Hakem et al., 2013). Nkaya (2004) detected that in Senegal, $20 \%$ of broiler carcasses were positive to the four plate test of which $4 \%$ containing [beta]lactam and tetracyclines.

In the studies carried out in our country and in many other countries, it was reported that antibiotics residues were detected in animal food submitted for consumption. Due to the fact that antibiotics residues in foodstuffs is a very serious problem affecting public health, livestock controls in coops should be performed by breeders more carefully and also it is understood that it is necessary to follow up these controls strictly. In order to determine the residues in food, supervision conducted by related public institutes should be tightened. This must be the case for especially poultry rearing industry. Selling and applying of banned medicine should be prevented.

\section{CONCLUSION}

Antibiotics used for animals caused developing of resistant bacteria and also some effects which resulted in depleting the importance of antibiotics used in human health. In treating animals that can be eaten or having food value, even the usage of low dose chloramphenicol can create risks for presence of residues and this, thus can harm human health. Because of these reasons, in European Union member countries, in United States of America and in Turkey among with many other countries the usage of chloramphenicol in animals having food value is banned. Also, maximum residue limit for tetracycline is stated in those countries mentioned above. Yet, in the light of the data acquired from the previous studies; it was concluded that antibiotics were used illegally in breeding animals that have food value. Due to this reason, specific and analytical methods are needed so as to observe chloramphenicol and tetracycline group antibiotics in animal food. Different methods such as liquid chromatograpy (LC), gas chromatography (GC) and immunoassay (ELISA) are being used for residual analysis. In accordance with the comission resolution 2002/657/EC; in order to confirm suspicious positive samples mass spectrometry (MS) is an efficient method and it has to be used together with chromatographic differentiation method. LC-MS/MS is a reliable and analytical method that can be used for "zero tolerance residual level" medicines in animal tissues.

In the conducted study, antibiotics residues above the limits determined by the authorities weren't detected in analyzed poultry samples. However, as detected antibiotics residues above MRL limits in animal food compose a potential risk factor in terms of food safety and public health; poultry and meat products should be analyzed in certain intervals on account of antibiotics residues. With the aim of preventing the risk that may occur, the frequency of supervision should be increased for production and sales companies. Suitable production and conservation conditions should be provided for broiler meats and other animal origin foods. Hereby, it must be aimed that the whole quality criteria and antibiotics residues in particular are suitable to Turkish Food Codex Notification of Meat Products until the end of shelf-life.

\section{ACKNOWLWDGEMENTS}

This work was financially supported by Adnan Menderes University (Grant Number VBH-YL2012/0001).

\section{REFERENCES}

Aarestrup, F. (2012). Sustainable farming: Get pigs off antibiotics. Nature, 486: 465-466.

Acet, A., Ates, M., Erganis, O. (1998). Determination of antimicrobial residues in animal tissues by agar diffusion technique. Journal of 
Selcuk University Faculty of Veterinary Medicine, 3: 197-205.

Akar F. (1991). Investigating some antibiotic residues with thin layer chromatography methods in chicken meat and liver that was sold in Ankara. The Scientific and Technical Research Council of Turkey.

Bergner-Lang, B., Bourgeois, B., Edelhauser, M., Klein, E., Lippold, R., Mollers, M., Pletscher, D. (1993). Chemical Drug Residue Analysis of Inhibitor-positive Samples of Meat, Kidney and Liver. Editors: Haagsma N, Ruiter A, Eysenberg PBC. Euro Residue II, Conferance of Residues of Veterinary Drugs in Food. Veldhoven, The Netherlands, 186-191 p.

Bryant Christie Inc Global MRL database (2016) Available at: https://www.globalmrl.com (Accessed: 22.03.2016)

Carrique-Mas, J. J., Trung, N.V., Hoa, N. T., Mai, H. H., Thanh, T. H., James. Campbell, J. A., et al. (2015). Antimicrobial Usage in Chicken Production in the Mekong Delta of Vietnam. Zoonoses Public Health, 1: 70-78.

Cháfer-Pericás, C., Maquieira, A., Puchades, R. (2010). Fast screening methods to detect antibiotic residues in food samples. TrAC Trends in Analytical Chemistry, 29(9): 1038-1049.

Chico, C., Rúbies, A., Centrich, F., Companyó, R, Prat, M.D., Granados, M., 2008. High-throughput multiclass method for antibiotic residue analysis by liquid chromatography-tandem mass spectrometry. Journal of Chromatography A, 1213(2): 189-199.

Codex alimentarius commission, veterinary drug residues in food (2016) Codex Veterinary Drug Residues in Food Online Database Available at: http://www.codexalimentarius.org/standards/v etdrugs/veterinary-drugs/en

(Accessed: 14.11.2016)

Do, M.H.N., Yamaguchi, T., Okihashi, M., Harada, K., Konishi, Y., Uchida, K., Bui, L.T., Nguyen, T.D., Phan, H.B., Bui, H.D.T., Nguyen, P.D., Kajimura, K., Kumeda,Y., Dang, C.V., Hirata, K., Yamamoto,Y. (2016). Scree.ning of antibiotic residues in pork meat in Ho Chi Minh
City, Vietnam, using a microbiological test kit and liquid chromatography/tandem mass spectrometry. Food Control, 69: 262-266.

European Commission (2002). Commission Decision 2002/657/EC of 14 August 2002 implementing Council Directive 96/23/EC concerning the performance of analytical methods and interpretation of results. OffJ L, 221: 8-36.

Farideh, G., Behrooz, F. and Abdollah, J. (2014). Detection of antibiotic residues in poultry carcasses in Mashhad poultry abattoir. Iranian Journal of Veterinary Science and Technology, 6(1): 3036.

Gomes, E. R. and Demoly, P. (2005). Epidemiology of hypersensitivity drug reactions. Current Opinion in Allergy and Clinical Immunology, 5: 309-316.

Hakem A., Y. Titouche, K. Houali, B. Yabrir, O. Malki, N. Chenouf, Y. Ahiaouis, M. Labiad, H. Ghenim, S. Kechih-Bounar, F. Chirila, A. Lapusan and N.I. Fit (2013). Screening of Antibiotics Residues in Poultry Meat by Microbiological Methods. University of Agricultural Sciences and Veterinary Medicine Cluj-Napoca. Veterinary Medicine, 70(1): 1843-5270.

Hussain, S., Khan, S., Ali, J., Sultan, A., Chand, N. and Rafiullah. (2013) Antibiotic residues in commercial poultry meat and egg. International Workshop on Dairy Science Park, Pakistan.

Lee, J.B., Chung, H..H, Chung, Y.H., Lee, K.G. (2005). Development of an analytical protocol for detecting antibiotic residues in various foods. Food Chemistry, 105: 1726-1731.

Martínez, U. Z. (2005). Health official: clenbuterol cases rising. Miami Herald, Mexico Edition, Available at: http://www.eluniversal.com.mx/miami/15989.h tml (Accessed: 28.11.2005).

Mavungu, J.D.D., Monbaliu, S., Scippo, M., Maghuin-Rogister, G., Schneider, Y., Larondelle, Y., Callebaut, A., Robbens, J., Peteghema, C.V., Saegera, S.D. (2009). LC-MS/MS multi-analyte method for mycotoxin determination in food 
supplements. Food Additives \& Contaminants: Part A, 26(6), 885-895.

Nkaya, T. (2004). Comparative study of the presence of antibiotic residues in the broiler muscles of the thigh and the breastbone in the Dakar region. Dakar, Senegal. Inter-State School of Veterinary Sciences and Medicine. Veterinary thesis.

Obekci J. (2002). Determination of the tetracycline group of antibiotics in chicken meat and liver by HPLC. Ministry of Agriculture and Rural Affairs.

Onal, A., Aydın, N., Ayaz, Y., Iscan, D., Savas, N. (1993). To be detected some antibiotics present in milk and meat by various methods. Journal of Veterinary Microbiology Institute, 7: 48-51.

Passantino, A. and Russo, C. (2008). Maximum Residue Levels of Veterinary Medicines in Relation to Food Safety: European Community Legislation and Ethical Aspects. Journal of Consumer Protection and Food Safety, 3: 351-358.

Raison-Peyron, N., Messaad, D., Bousquet, J., and Demoly, P. (2001). Anaphylaxis to beef in penicillin-allergic patient. Allergy, 56: 796-797.
Sajid, A., Kashif, N., Kifayat, N. and Ahmad,S. (2016). Detection of antibiotic residues in poultry meat. Pakistan Journal of Pharmacentical Sciences, 29(5): 1691-1694.

Salehzadeh, F., Madani, R., Salehzadeh, A., Rokhni, N. and Golchinefar, F. (2006) Oxytetracycline residues in chicken tisuues from Tehran slaughterhouses in. Iranian Journal of Nutrition Sciences \& Food Technology, 5(4): 377-381.

Tajik, H., Malekinejad, H., Razavi-Rouhani, S.M., Pajouhi, M.R., Mahmoudi, R. and Haghnazari, A. (2010) Chloramphenicol residues in chicken liver, kidney and muscle: A comparison among the antibacterial residues monitoring methods of four plate test, ELISA and HPLC. Food and Chemical Toxicology, 2464-2468.

Wang, H., Ren, L., Yu, X., Hu, J., Chen, Y., He, G. and Jiang, Q. (2017). Antibiotic residues in meat, milk and aquatic products in Shanghai and human exposure assessment. Food Control, 80: 217-225. 